\title{
Biological Control of Groundnut Root Rot in Farmer's Field
}

\author{
Pratibha Sharma ${ }^{1}$, Mahesh Kumar Saini ${ }^{1}$, Swati Deep ${ }^{1} \&$ Vignesh Kumar $^{1}$ \\ ${ }^{1}$ Division of Plant Pathology, Indian Agricultural Research Institute (IARI), India \\ Correspondence: Dr. Pratibha Sharma, Professor, Division of Plant Pathology, Indian Agricultural Research \\ Institute, New Delhi-110012, India. Tel: 91-11-2584-8418; 91-981-011-9397. E-mail: pratibha@iari.res.in; \\ psharma032003@yahoo.co.in
}

\author{
Received: March 28, 2012 Accepted: April 23, 2012 Online Published: June 29, 2012 \\ doi:10.5539/jas.v4n8p48 \\ URL: http://dx.doi.org/10.5539/jas.v4n8p48
}

The research is sponsored by Technology Information, Forecasting and Assessment Council (TIFAC), Department of Science and Technology (DST), Government of India, New Delhi, India

\begin{abstract}
Groundnut is an important oilseed crop predominantly grown in Rajasthan, India and has suffered a 55 to 85 percent root rot disease caused by multiple pathogen complex mainly Aspergillus niger, Apergillus flavus, Sclerotium rolfsii, Thievaliopsis basicola, Rhizoctonia solani and Pythium aphanidermatum perennating in soil and seed. Trichoderma harzianum (Th3) was used against Groundnut varieties (GG-10, GG-20, M-13 and Local varieties) to reduce the yield loss by root rot disease during the year 2009 and 2010 in farmers' fields in twelve villages in the Jaipur district of Rajasthan. The field trials were conducted by the application of Trichoderma harzianum in the form of powder and liquid bio-formulation. Trials were conducted by treating the soil, seed and foliage with powdered bio-formulation (Th3 SD, SA) at $5 \mathrm{~g}$ per $\mathrm{kg}$ seed/soil followed by spray treatment with liquid bio-formulation (Th3 FS) at $5 \mathrm{ml} / 1$ along with recommended IPM practices. The crops under farmer practice were significantly lower in yields with the diagnostic blackening symptoms travelling from roots to stem affecting the vascular system followed by shredding at root-stem internodes resulting in complete wilting and plant death while in Th3 treated crop blackening reduced and the root vascular system was free of disease. Maximum values of yield (39.17 Q/ha), R.C. Index (0.15), C.F.U. $\left(38.5 \times 10^{6}\right)$, and lowest root rot incidence $(14.03 \%)$ was recorded in the Th3 treated groundnut crops. Increase in annual income also encouraged farmers to use the Trichoderma technology. Participatory approach and interaction between researcher and farmers helped in quick adoption and dissemination of use of biocontrol agents for groundnut growers in Rajasthan state, India.
\end{abstract}

Keywords: groundnut, root rot, Trichoderma harzianum (Th3), biological control, farmer participation

\section{Introduction}

Groundnut (Arachis hypogea) is considered to be one of the most important oilseed crops in the world. It originated in South America (Southern Bolivia/north west Argentina region) where it was cultivated as early as 1000 B.C. (Wiess, 2000). Today, it is grown in areas between 40 degrees south and 40 degrees North of the equator, where average rainfall is 500 to $1200 \mathrm{~mm}$ and mean daily temperatures are higher than $20^{\circ} \mathrm{C}$ (Pattee \& Young, 1982). It is grown in over 100 countries of the world and plays a crucial role in the world economy. Groundnut production has reached the mark of around 34 million tons. China (followed by India), is the largest producer of this oilseed crop in the world. The groundnut oil production hovers around 8 million tons annually. The production price of groundnut in India is competitive globally. The market price is only 16 percent above the producer price (Rama Rao et al., 2000).

The planting season in India starts from May till August. It largely depends on the time of arrival of monsoon season in the country. Harvesting starts from September to December. In India, two-thirds of the crop is cultivated as a summer (Kharif) crop (crops sown in rainy season and harvested in autumn season) and the rest is produced as winter crop (crops sown in autumn season and are harvested in winter season) (Basu \& Ghosh, 1995).

The groundnut seed is a good source of edible oil and proteins in the form of oil cake, which can also be used as an animal fodder and fertilizer. It also has some industrial uses like in paint, varnish, lubricating oil, soap, 
furniture polish etc. Groundnut root rot disease also known as 'kalijad' (in hindi), affects the production and quality of groundnut crop, it is a seed-borne disease caused by a pathogen complex of Aspergillus niger Van Tieghem and Aspergillus flavus J H F Link of the family Trichocomaceae, Thievaliopsis basicola (Berk. \& Broome) Ferraris of the family Ceratocystidaceae, Rhizoctonia solani J.G. Kuhn of the family Ceratobasidiaceae and Pythium aphanidermatum (Edson) Fitzp. of the family Pythiaceae. The disease progresses in different forms like collar rot (A. niger), stem-rot (S. rolfsii), root-rot (M. phaseolina $=R$. bataticola), along with aflatoxin contamination (Aspergillus flavus and A. parasiticus). Around 55 to 85 percent crop loss was recorded in India with diagnostic blackening symptoms that travel from roots to stem affecting the vascular system, followed by shredding at root-stem internodes and resulting in complete wilting and plant death.

Though chemical pesticides have played an important role in increasing groundnut production and management of root rot, their indiscriminate use for the control of pests has led to several environmental problems such as development of resistance in pests to pesticides, pesticide residues and the destruction of beneficial parasites and predators of pests. Thus other alternative disease management options were considered among which biological control appears promising. Majority of the existing biocontrol agents for management of soil-borne diseases, were isolated from the rhizosphere. There is a possibility to explore antagonists from other habitats as potent biocontrol agents (Manjula et al., 2002). Some biocontrol agents have also been isolated from the seed surfaces (Guanlin et al., 1997). Some species of the genus Trichoderma have been used as effective biocontrol agents against soil-borne, foliar and postharvest phytopathogenic fungal pathogens (Chet, 1990; Cortes et al., 1998; Sharma et al., 2011) in several plant crops (Kubicek et al., 2001; Sharma et al., 2001, 2003, 2004, 2005; Sharma $\&$ Sain, 2005) including groundnut (Podile \& Kishore, 2002). These fungi may also promote plant growth (Inbar et al., 1994) and have the ability to colonize root surfaces and the cortex (Kleifeld \& Chet, 1992; Yedidia et al., 1999). Trichoderma spp. was found to colonize the root epidermis and outer cortical layers and release bioactive molecules that cause walling off of the Trichoderma thallus. At the same time, the transcriptome and the proteome of plants are substantially altered. As a result disease resistance of the plant increased along with plant growth and nutrient uptake (Harman, 2006; Sharma et al., 2011). Trichoderma spp. are widely used in agriculture as biopesticides, bioprotectants, biostimulants, and biofertilizers on a wide variety of plants (Harman \& Kubicek, 1998). It has been found from different research works that Trichoderma can reduce the disease incidence caused by Aspergillus niger (Gajera et al., 2011; Rajkonda et al., 2011), Aspergillus flavus (Reddy et al., 2009), Sclerotium rolfsii (Abdel-Kader et al., 2011; Manjula et al., 2004), Pythium aphanidermatum (Devaki et al., 1992; Sharma \& Sain, 2003, 2005, 2006; Mishra, 2010), Rhizoctonia solanii (Abdel-Kader et al., 2011; Gveroska \& Ziberoski, 2011). Both T. viride and T. harzianum were found to be capable of reducing the sclerotial population of M. phaseolina (Sharma, 1982; Sharma \& Dureja, 2004).

All the above studies are based on lab and green house conditions. To validate the performance of Trichoderma harzianum (Th3) strain developed in Biological Control Lab, a technology was evaluated under Department of Science and Technology - Technology Information Forecasting and Assessment Council (DST - TIFAC) funded project entitled "On Farm Demonstration and Commercial Production of Trichoderma as Biopesticide and Growth Promoter" at farmers' groundnut fields in the state of Rajasthan (Four varieties viz., M13, GG-10, GG-20 and Khejroli Local) against root rot disease which was the epidemic disease.

\section{Materials and Methods}

\subsection{Selection of the Study Site and Baseline Information}

Under DST-TIFAC funded project entitled "On Farm Demonstration and Commercial Production of Trichoderma as Biopesticide and Growth Promoter", the district of Jaipur in Rajasthan was selected for the study. The district has some unique agro climatic features such as it being in the "Semi-Arid Eastern Plains". The area stretches from $27^{\circ} 00^{\prime} \mathrm{N}$ Latitude to $75^{\circ} 82^{\prime}$ E Longitude, and covers $11,152 \mathrm{~km}^{2}$ (Av. elevation- $431 \mathrm{~m}$ ), with clay $\&$ sandy soil and an annual rainfall of $650 \mathrm{~mm}$. Temperature varies from $25-45^{\circ} \mathrm{C}$ in the summer and from 5 $22^{0} \mathrm{C}$ in the winter. In 2008, this part of Rajasthan faced severe problems caused by the Groundnut Root rot disease (Kalijad). Farmers growing groundnuts suffered great losses socio-economically. As groundnut is one of the major crops grown in Rajasthan, it lead to heavy damage in both yield and quality of the crop, and the situation was taken as a challenge for biological control of the epidemic disease.

\subsection{Trichoderma Technology, the Biocontrol Strain and C.F.U. (Colony Forming Unit) of Biopesticide}

The bioformulation used as inoculants in different seed, seedling and foliar treatments was prepared by using Trichoderma harzianum (Th3) (ITCC No.-5593 \& Gene Accession No. EU 365835) strain in powdered (10 ${ }^{8}$ $\mathrm{CFU} / \mathrm{g})$ and liquid $\left(10^{12} \mathrm{CFU} / \mathrm{g}\right)$ forms, developed by the Biocontrol Laboratory, Division of Plant Pathology, Indian Agriculture Research Institute, New Delhi. This Trichoderma harzianum strain (Th3) was found to be 
resistant against the fungicide Carbendazim (Sharma \& Dureja, 2004), with antagonistic activity against major soil-borne and air-borne plant pathogens. Sorghum-based powdered bio-formulations and metabolite-based liquid bio-formulations were produced in large quantities under laboratory conditions and distributed to different groundnut farmers for use against different plant pathogens, especially against the groundnut root rot diseases.

\subsection{Field Studies/ Experimental Design}

Field demonstrations were conducted as trials on farmers' fields at twelve different villages viz., Raholi, Thali, Jaiypura, Samode, Takarda, Khejroli, Dhodhasar, Vijaysinghpura, Sultanpura, Kaladera, Singodh and Hanutia in the Jaipur district of Rajasthan, India for two years (2009 and 2010) during the 'Summer' season (July-November). A total of 105 farmers registered under the project for the demonstration of the Trichoderma technology, and were provided with Trichoderma harzianum bio-formulations. Based on soil type and cultivation procedures, the twelve villages were divided into four different groups (Table 1) and one representative field from each group considered in the present study. Four different Groundnut varieties viz., GG10, GG20, M13 and a Local variety (Khejroli local) were sown in 1 ha area with a spacing of $30 \times 30 \mathrm{~cm}$. At sowing time, the soil and seeds were treated with the powdered bio-formulation (Th3 SD, SA) @ $5 \mathrm{~g} / \mathrm{kg}$. Fertilizers used were Farm yard manure (FYM), Diammonium Phosphate (DAP), Urea and Super Phosphate @ 6-7 Tons / hectare (ha), 1.5-2.0 Quintal (Q)/hectare (ha), 1.5-2.0 Q/ha, and 3.5-4.0 Q/ha, respectively, while Endosulphan (1.5-2.5 l/ha) was used for insect control. Irrigation was done by sprinklers and canals at an interval of 20, 40, 60 and 80 days after sowing. Weeds were manually removed from the crop. During flowering, the spray treatment of the liquid bio-formulation (Th3 FS) @ 4ml/L was conducted. The treatments followed the application module of Trichoderma harzianum (Th3) bio-formulation (Table 2), as the conventional system vis a vis farmers' practice (FP), using application of agronomic factors and pest control commonly practiced by the local farmers in the non-Th plots.

Table 1. Grouping of villages based on the soil type and water irrigation facility available

\begin{tabular}{lll}
\hline Group & \multicolumn{1}{c}{ Villages } & Soil type and availability of irrigation facility \\
\hline I & Raholi, Thali, Hanutia, Jaipura & Dry sandy area with less irrigation facility \\
II & Dhodhsar, Khejroli, Singodh & Sandy area with good irrigation facility \\
III & Vijaysinghpura, Sultanpura, Samode & Sandy loamy soil with clay and good irrigation facility \\
IV & Takerda, Kaladera & Sandy loamy soil with clay and less irrigation facility \\
\hline
\end{tabular}

Table 2. Application module of Trichoderma harzianum (Th3) bioformulation in fields against Groundnut root rot disease during summer, 2009 and 2010 season

\begin{tabular}{llrl}
\hline Crop Stages & \multicolumn{1}{c}{ Mode of Treatment } & Dose & Management \\
\hline Soil & Powder bio-formulation & $4 \mathrm{~g} / \mathrm{kg}$ soil & Soil borne diseases \\
Seed/Seedling & Powder bio-formulation & $4 \mathrm{~g} / \mathrm{kg}$ soil & Seed borne diseases \\
Flowering/ & Powder and Liquid & Broadcasting of solid & Foliar and soil borne diseases \\
Foliage & bio-formulation & bio-formulation $+\mathrm{FYM}$, & Liquid $4 \mathrm{ml} / \mathrm{L}$ \\
Before & Liquid bio-formulation & $4 \mathrm{ml} / \mathrm{L}$ & Foliar diseases \\
harvesting & & & \\
\hline
\end{tabular}

Table 3. Scheduled modules for application of Trichoderma harzianum (Th3) bio-formulation in fields against Groundnut root rot disease during the summer, 2009 and 2010 season

\section{Bio-control module}

\begin{tabular}{cccccc}
\hline \multicolumn{2}{c}{ One year protection 2009} & Alternate year protection (2009/2010) & One year protection 2010 & \multicolumn{2}{c}{ Two year protection (2009\&2010) } \\
\hline T1 & $\mathrm{T} 2$ & $\mathrm{~T} 3$ & $\mathrm{~T} 4$ & $\mathrm{~T} 5$ & $\mathrm{~T} 6$ \\
$2009 \mathrm{Th}$ & $2009 \mathrm{FP}$ & $2009 \mathrm{Th}$ & - & - & $2009 \mathrm{Th}$ \\
- & - & $2010 \mathrm{FP}$ & $2010 \mathrm{Th}$ & $2010 \mathrm{FP}$ & $2010 \mathrm{Th}$ \\
\hline
\end{tabular}

Where, Th: Th3 Treated and FP: Farmer's practice 


\subsection{Mode of Adoption of Trichoderma Technology}

The biological control of Groundnut Root Rot was observed with three scheduled modules of Protection (One year, Two Year and alternate Year in 2009-10) (Table 3). This module was prepared to observe and compare the effect of the Th3 bio-formulation applied to control the disease incidence and yield of groundnut production. In one year protection, groundnut crops at different fields were treated with Th3 bio-formulations according to application procedures during the year 2009 (T1 and T2) and 2010 (T4 and T5) alone. Under two year protection, the FP crop and Th-treated groundnut crop were compared for both years 2009 and 2010 (T6). In alternate year protection, the Th-treated crop of 2009 was compared with the FP crop of 2010 (T3).

\subsection{Data Collection}

Infected seed samples and Groundnut plant parts were regularly tested in the laboratory before and after Th3 treatment. Disease Incidence of Groundnut Root Rot and Yield of Groundnut were recorded. The periodic observations of Rhizosphere Competence (R.C) Index and colony forming unit (CFU) count were also recorded at three different stages (Seedling, Flowering and Preharvesting) of groundnut crops.

\subsubsection{Collection of Soil Samples}

Rhizosphere, rhizoplane and bulk soil were collected for sampling. For rhizosphere soil from each field, ten plants were dug out with a spade, the roots gently lifted from the bulk soil and large soil aggregates dislodged from the roots. Around $200 \mathrm{~g}$ of soil was collected in plastic bags and the Trichoderma population per gram of soil was calculated.

Rhizoplane soil of Groundnut was investigated for differences in Trichoderma species population numbers and diversity. The root systems of the plants was bagged in zip-lock polyethylene bags and stored at $8^{\circ} \mathrm{C}$ until processing. In addition to rhizosphere and rhizoplane soil, the bulk soil was also sampled at different times during the three growing stages i.e, seedling, flowering and pre-harvesting. The bulk soil is defined as the soil not affected physically, chemically or biologically by the root of a plant (Lavelle \& Spain, 2001). Indigenous Trichoderma population number in the bulk soil was also measured.

\subsubsection{Sampling of Soil and Roots}

The soil sampling was carried out on the same dates as the rhizosphere and rhizoplane soil sampling. The effects of Th3 treatments on the population of indigenous Trichoderma species was evaluated by soil dilution plating to count colony forming units (CFU) (Zhang et al., 2005). After field sampling, the rhizosphere and rhizoplane soil was processed for soil dilution plating. One $10 \mathrm{~g}$ soil sub-sample was taken from each of the sampled plants, for a tenfold serial dilution for each field. The $10 \mathrm{~g}$ sample was placed into a $150 \mathrm{~mL}$ sterile conical flask with $90 \mathrm{~mL}$ of sterile distilled water. The flasks were placed on a shaker for $10 \mathrm{~min}$ at $150 \mathrm{rpm}$. The soil suspension was serially diluted and $100 \mu \mathrm{l}$ of each dilution from $10^{-2}$ to $10^{-8}$ were spread onto Pertiplates containing Trichoderma Selective Medium (TSM) plates and also on Potato dextrose agar (PDA) plates. The plates were then sealed and incubated in the dark at $28^{\circ} \mathrm{C}$ for 10 days to allow fungal growth. Colony forming units were recorded via colony counter.

In addition, root fragments were placed on $1 \mathrm{~cm}$ TSM agar discs to detect endophytes from the root surface. The roots were incubated in the dark at $28^{\circ} \mathrm{C}$ for 10 days to observe any fungal growth.

\subsubsection{Calculation of Rhizospheric Competence (RC) Index}

The competitiveness of Biological Control Agents (BCAs) with other soil inhabitants in colonization of root surfaces of the host plants is termed as rhizosphere competence (RC). RC index of Trichoderma harzianum (Th3) was measured as per the formula of Ahmad and Baker (1987).

$$
\mathrm{RC} \text { index }=\sum_{\mathrm{N}}^{\mathrm{i}=1}[\log (\mathrm{Pi}+1) \ln (\mathrm{Di}+1)] / \mathrm{n}
$$

Where $P$ is the population density per mg of rhizosphere/rhizoplane/bulk soil, $D$ is the root depth, and $n$ is the total root length.

The RC index was calculated for both FP and Th-treated crops in 2009-2010 and at the seedling, flowering and pre-harvesting stages of the crop.

\subsubsection{Cost of Production}

Cost of production was calculated by taking into consideration the expenditure incurred on cost for field 
preparation, fertilizer application, hoeing and weeding, pesticide application, material cost like seed, pesticides, bio control agents (Th3 bio-formulation), IPM inputs, fertilizers, and irrigation. The data on yield (kg/ha), cost of production (Rs/ha) including all inputs and cost of plant protection (Rs/ha) and total return (Rs/ha) were used to determine the cost benefit ratio.

\subsubsection{Data Analysis}

Data were statistically analyzed using analysis of variance (ANOVA) at a significance level $(p<0.0001)$ using the statistical software PRISM version 3.0.

Calculation of Disease Incidence

The disease incidence was calculated as follows

$$
\begin{gathered}
\text { PPI }=\quad \frac{\text { Number of Infected plants }}{\text { Total Number of plants/leaves observed }} \times 100 \\
\text { Sum of Numerical grade }
\end{gathered}
$$

The entire biocontrol module for the years 2009-10 was compared with each other to see the difference between FP and Th-treated groundnut crop (all four varieties). Reduction over control (ROC) was also calculated.

\section{Results}

\subsection{Reduction in Groundnut Root Rot Disease Incidence}

The comparison of percentage disease incidence (Table 4, Figure 1) was done as per the biocontrol disease module following different treatments viz., T1 to T6. There was no major difference among the four different varieties of groundnut (viz., M13, GG10, GG20 and Khejroli local). Under the one year protection module of 2009, the treated (T1) groundnut crop showed a marked reduction of about $50 \%$ in disease incidence in comparison to the farmer practice (FP) (T2) crop. Maximum disease reduction was found in the groundnut variety Khejroli local (52.41\%) than the other three varieties (viz., GG10 (49.97\%), M13 (47.84\%) and GG20 $(46.76 \%))$. Similar observations were observed in the case of one year protection during 2010 (T4) where there was also a marked reduction in groundnut root rot incidence compared to FP crop (T5). The reduction over control in 2010 groundnut crop ranged from 40.37\% (GG20) to 45.74\% (Khejroli local). The two year protection module (T6) was found to be the best as disease incidence reduction of $53.76 \%$ to $65.51 \%$ were observed in the different groundnut varieties due to the continuous application of Th3 bio-formulation. The alternate year protection module of biocontrol (T3) showed a residual effect of Th3 bio-formulation on the reduction of groundnut root rot from $27.85 \%(\mathrm{GG} 20)$ to $35.44 \%$ (M13).

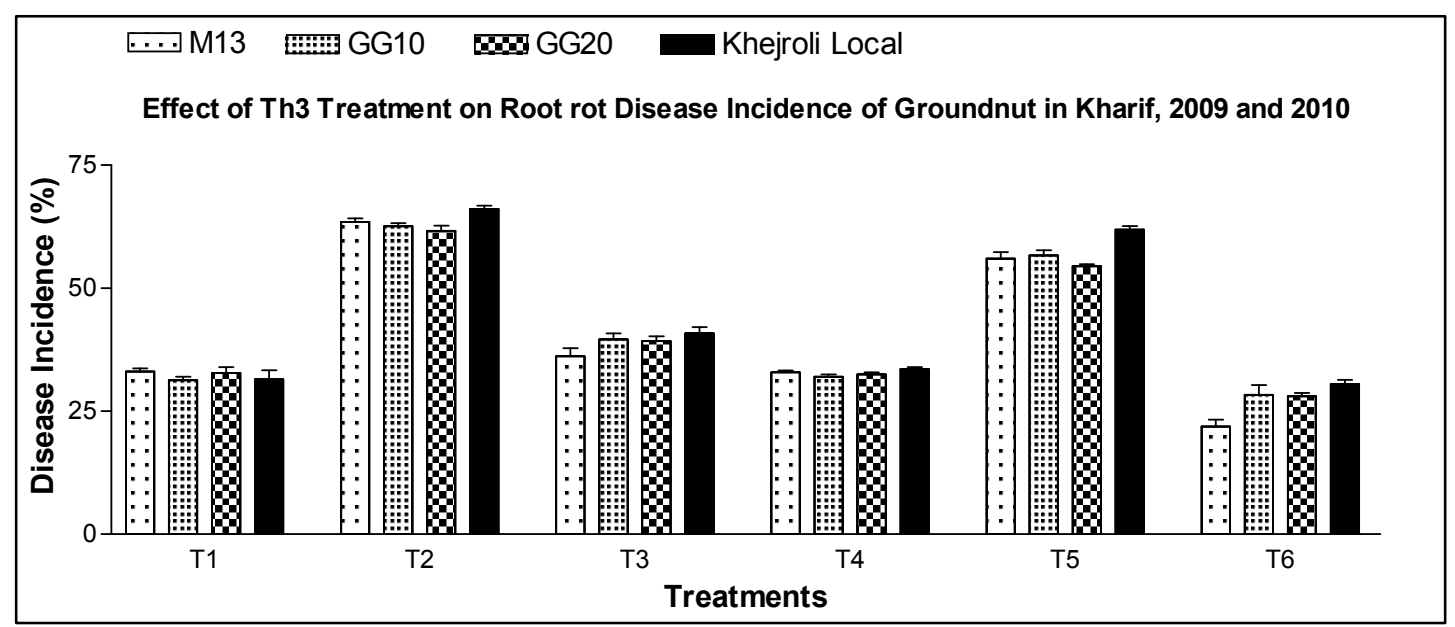

Figure 1. Effect of Trichoderma harzianum (Th3) Treatment on Root rot Disease Incidence of Groundnut in Summer (Kharif), 2009 and 2010. Where, T1 to T6: Scheduled Th3 treatments. Error bar indicates CD value at $\mathrm{p}<0.0001$ 
Table 4. Effect of Trichoderma harzianum (Th3) Treatment on Root rot Disease Incidence of Groundnut during the summer, 2009 and 2010 season

\begin{tabular}{|c|c|c|c|c|c|c|}
\hline \multirow[t]{5}{*}{ Varieties } & \multicolumn{2}{|l|}{ One Year } & \multirow{3}{*}{$\begin{array}{l}\text { Alternate year } \\
\text { Protection } \\
(2009 / 2010)\end{array}$} & \multicolumn{2}{|l|}{ One Year } & \multirow{3}{*}{$\begin{array}{l}\text { Two Year } \\
\text { protection } \\
\text { (2009 and 2010) }\end{array}$} \\
\hline & Protection & & & Protection & & \\
\hline & 2009 & & & 2010 & & \\
\hline & $\mathrm{T} 1$ & $\mathrm{~T} 2$ & $\mathrm{~T} 3$ & $\mathrm{~T} 4$ & $\mathrm{~T} 5$ & T6 \\
\hline & 2009Th & 2009FP & $2009 \mathrm{Th}+2010 \mathrm{FP}$ & 2010Th & 2010FP & $2009 \mathrm{Th}+2010 \mathrm{Th}$ \\
\hline M13 & 29.83(33.09) & $79.98(63.44)$ & $34.88(36.15)$ & 29.48(32.88) & $68.70(56.02)$ & $14.03(21.88)$ \\
\hline ROC (2009) & 47.84 & - & 43.02 & 48.17 & - & 65.51 \\
\hline ROC (2010) & & & $35.44^{*}$ & 41.31 & & 60.94 \\
\hline GG-10 & $27.03(31.31)$ & $78.78(62.58)$ & $40.63(39.58)$ & $28.13(32.03)$ & $69.73(56.64)$ & $22.78(28.36)$ \\
\hline ROC (2009) & 49.97 & - & 36.75 & 48.82 & - & 54.68 \\
\hline ROC (2010) & & & $30.12 *$ & 43.45 & & 49.93 \\
\hline GG-20 & $29.40(32.81)$ & $77.35(61.63)$ & $39.70(39.3)$ & $28.85(32.48)$ & $66.23(54.47)$ & $22.15(28.06)$ \\
\hline ROC (2009) & 46.76 & & 36.23 & 47.30 & - & 54.47 \\
\hline ROC (2010) & & & $27.85^{*}$ & 40.37 & & 48.48 \\
\hline Khejroli Local & $30.8531 .44)$ & $83.53(66.07)$ & $42.80(40.85)$ & $30.60(33.58)$ & $77.65(61.89)$ & $25.63(30.55)$ \\
\hline ROC (2009) & 52.41 & & 38.17 & 49.17 & & 53.76 \\
\hline ROC (2010) & & & $33.99 *$ & 45.74 & & 50.64 \\
\hline SEM & & & & & & \\
\hline CD (0.0001) & & & & & & \\
\hline
\end{tabular}

Values are mean of four replications; Values in parentheses are retransformed (original) value of arc sin transformation; CD - critical differences; *Residual effect of Th3, Where, T1 to T6: Scheduled Th3 treatments, Th: Th3 Treated and FP: Farmer's practice

\subsection{Effect on the Yield of Groundnut}

The yield of Groundnut crop in summer season during 2009-10 was recorded in Quintal production per hectare. Comparison of yield of Groundnut was compared following the same biocontrol module of the six treatments of Th3 bio-formulation. About $40 \%$ increase was observed over farmers practiced (FP) groundnut crop in continuous application of bio-formulation (T6). The Th-treated crop yielded more than the FP crop (Table 5, Figure 2). The yield of all varieties of groundnut was almost similar to each other under different treatments. One year protection of groundnut in both 2009 (T1) and 2010 (T4) showed a marked increase in yield in comparison to the FP crop in 2009 (T2) and 2010 (T5), respectively. The average yield in the one year protection was around $36 \mathrm{Q} / \mathrm{h}$ which was $20-30 \%$ more than the yield of FP crops in both seasons. The average yield of alternate year protected (T3) groundnut crop was about $30 \mathrm{Q} / \mathrm{h}$ with a residual effect of Th3 of about $2-5 \%$.

Table 5. Effect of Trichoderma harzianum (Th3) bioformulation on the yield of Groundnut during the summer 2009 and 2010 season

One Year Protection 2009 Alternate year Protection One Year Protection 2010 Two Year protection

$(2009 / 2010)$

(2009 and 2010)

\begin{tabular}{lllllll}
\hline Varieties & T1 & T2 & T3 & T4 & T5 & T6 \\
& 2009Th & $\mathbf{2 0 0 9 F P}$ & $\mathbf{2 0 0 9}$ Th $+\mathbf{2 0 1 0}$ FP & $\mathbf{2 0 1 0}$ Th & $\mathbf{2 0 1 0}$ FP & $\mathbf{2 0 0 9}$ Th+ 2010 Th \\
M-13 & $\mathbf{3 5 . 9 8}$ & $\mathbf{2 9 . 2 3}$ & $\mathbf{3 0 . 0 5}$ & $\mathbf{3 6 . 1 0}$ & $\mathbf{2 9 . 4 3}$ & $\mathbf{3 8 . 7 0}$ \\
IOC (2009) & 23.09 & & 2.80 & 23.50 & & 32.40 \\
IOC (2010) & & & 2.11 & 22.66 & & 31.50 \\
\hline
\end{tabular}




\begin{tabular}{lllllll}
\hline GG-10 & $\mathbf{3 6 . 4}$ & $\mathbf{2 8 . 1 3}$ & $\mathbf{3 0 . 4 0}$ & $\mathbf{3 6 . 9 0}$ & $\mathbf{2 8 . 9 3}$ & $\mathbf{3 9 . 1 5}$ \\
IOC (2009) & 29.40 & & 8.07 & 31.18 & & 39.17 \\
IOC (2010) & & & 5.08 & 27.55 & & 35.33 \\
GG-20 & $\mathbf{3 5 . 8}$ & $\mathbf{2 7 . 8}$ & $\mathbf{2 7 . 9 0}$ & $\mathbf{3 6 . 2 0}$ & $\mathbf{2 8 . 2 8}$ & $\mathbf{3 8 . 5 0}$ \\
IOC (2009) & 28.78 & & 0.36 & 30.21 & & 38.49 \\
IOC (2010) & & & -1.34 & 28.00 & & 36.14 \\
Khejroli Local & $\mathbf{3 5 . 4 3}$ & $\mathbf{2 7 . 1 8}$ & $\mathbf{2 7 . 7 5}$ & $\mathbf{3 5 . 5 0}$ & $\mathbf{2 7 . 2 5}$ & $\mathbf{3 6 . 7 5}$ \\
IOC (2009) & 30.35 & & 2.10 & 30.61 & & 35.20 \\
IOC (2010) & & & 1.83 & 30.27 & & 34.86 \\
SEM & & & & 0.52 & & \\
CD (0.0001) & & & & 2.07 & & \\
\hline
\end{tabular}

Values represent mean of four replications. Where, T1 to T6: Scheduled Th3 treatments, Th: Th3 Treated and FP: Farmer's practice, CD: critical differences.

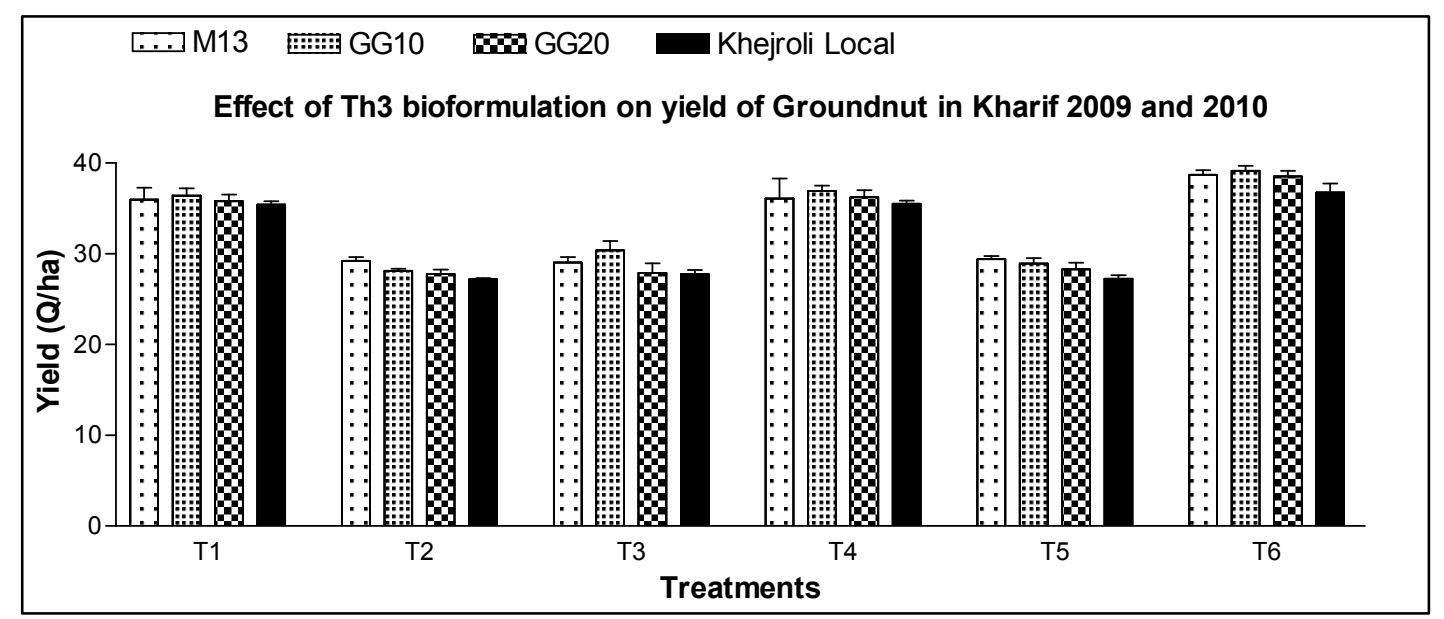

Figure 2. Effect of Trichoderma harzianum (Th3) bioformulation on the yield of Groundnut in Summer (Kharif) during 2009 and 2010. Error bar indicates CD value at $\mathrm{p}<0.0001$. T1 to T6: Scheduled Th3 treatments

\subsection{Effect on the Rhizospheric Competence of Th3 in Groundnut Crop}

Among all the treatments under different protection modules, the Th fields showed a higher rhizospheric competence index than the FP ones (Figure 3). The two-year protection module was the most effective for colonization of Th3 on rhizosphere of different groundnut varieties. The highest RC index value ranged from 0.09 to 0.15 under the two-year protection i.e., continuous treatment (T6) of groundnut crop in a series. The one year protection module ( $\mathrm{T} 1$ and $\mathrm{T} 4$ ) had ranges from 0.06 to 0.15 , whereas the completely unprotected (T2 and T5) crop varieties under FP showed the least RC index of 0.00 to 0.03 . In the FP crop of 2010 (T3), the value increased more than the FP crop of 2009 (T2) as it was having some residues of Th3 treatment of the previous year, and so RC index ranged from 0.02-0.11. In the protected groundnut crop of 2010 (T4), the treated crop was observed to be having high RC index value in comparison with farmer-practiced (T5) crops. The RC index was shown to be more in case of groundnut crops at pre-harvesting stage. And all the varieties had almost equal RC Index values at the different treatments.

\subsection{Economic Growth of the Farmers}

Total yield of Groundnut was recorded in Trichoderma-treated (Th) and farmer-practiced (FP) fields. On the average, the Trichoderma treatment increased marketable yield by 30 percent. Economic analysis of the data (Table 6) also showed higher economic returns and benefit-cost ratios in Th practice (Rs 119286/ha, 1:6.5) as compared to farmers practice (Rs 76635.5/ha, $1: 4.7$ ). 
Table 6. Mean yield and economics of Groundnut cultivation under Farmer Practice and Trichoderma harzianum (Th3) bio-formulation in the Jaipur district during the 2009 and 2010 season

\begin{tabular}{lllllll}
\hline Parameter & 2009 & & 2010 & & \multicolumn{2}{l}{$\begin{array}{l}\text { Pooled Mean } \\
\text { (2009 and 2010) }\end{array}$} \\
\cline { 2 - 7 } & & & & & Th & FP \\
\hline $\begin{array}{l}\text { Total cost of production (Rs/ha) } \\
\text { (All inputs) }\end{array}$ & 20600 & 19600 & 22630 & 21630 & 21615 & 20615 \\
Mean Yield (Q/ha) & & & & & & \\
Rate of Groundnut selling (Rs/Q) & 3200 & & 3500 & & 3350 & \\
Total Returns (Rs/ha) & 134272 & 71264 & 147560 & 125230 & 140901 & 97250.5 \\
Net Returns (Rs/ha) & 113672 & 51664 & 124930 & 103600 & 119286 & 76635.5 \\
Cost Benefit Ratio & $1: 6.5$ & $1: 3.6$ & $1: 6.5$ & $1: 5.8$ & $1: 6.5$ & $1: 4.7$ \\
\hline
\end{tabular}

Where, Th: Th3 Treated and FP: Farmer's practice

\section{Discussion}

India is one of the largest producers of oilseeds in the world and this sector occupies an important position in the agricultural economy. Rajasthan state occupies a prominent place in the oilseeds production of India with maximum production by one of the important oilseed crop Groundnut (Jain et al., 2005). Since seedling crown rot, collar rot, stem and pod rot, and dry root rot are important soil-borne diseases which affect the groundnut crop in epidemic proportions, a biocontrol technology was transferred to the door step of the groundnut farmers who had suffered yield loss for years. This was the first attempt of the use of a Biocontrol agent Trichoderma harzianum (Th3) in that state of the country, which gave an overwhelming response by the farmers. A significant increase in yield (39.17 Q/ha) (Table 4/Figure 2) and lowest root rot incidence (14.03\%) (Table 3/Figure1) was recorded. Disease progression was also studied in relation to disease appearance in treated fields where symptoms penetrated from roots to stem causing blackening, which affected the vascular system followed by shredding at root-stem internodes and resulting in complete wilting and plant death. The Th treatment improved the health of the crop, with a two-fold increase in yield (Figure 2) as compared to the farmer-practiced crop. Trichoderma harzianum (Th3) was found to effectively control the Groundnut root rot epidemic (Kalijad disease) in Rajasthan. The bioefficacy of Th3 strain has already been tested in different crops like cauliflower, cabbage, chilli, tomato, and against a large number of soil and foliar pathogens namely Pythium aphanidermatum, Phytophthora parasitica, Fusarium oxysporum, Sclerotinia sclerotiorum, Sclerotium rolfsii, Phomopsis vexans, Alternaria alternata, Rhizoctonia solani, Colletotrichum capsici (Ahuja et al., 2012; Sharma et al., 2001, 2003, 2004, 2005, 2006; Sharma \& Dureja, 2004; Sharma \& Sain, 2004, 2005; Qais et al., 2005). Effective bio-formulation of the Trichoderma harzianum (Th3) strain was formulated and validated (Sharma and Sain, 2003 a \& b).

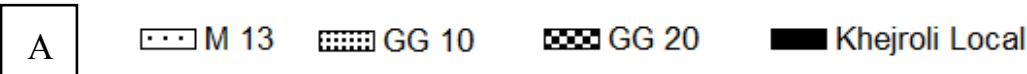

\section{Effect on R.C.Index of Th3 during Seedling Stage of Groundnut in Kharif, 2009 and 2010}

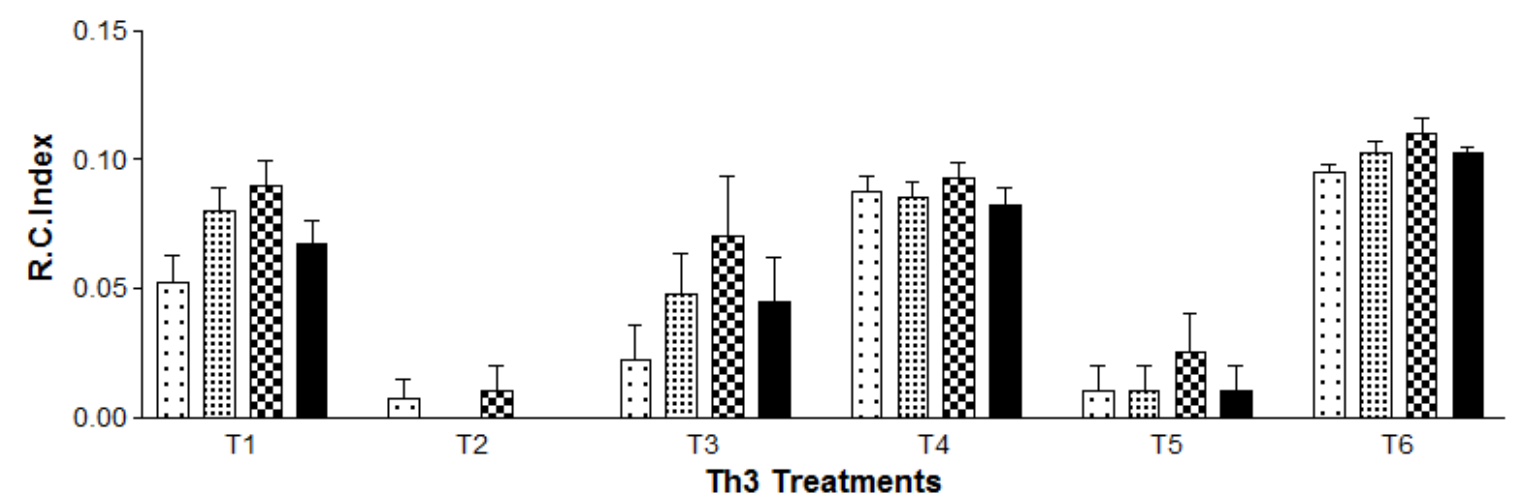



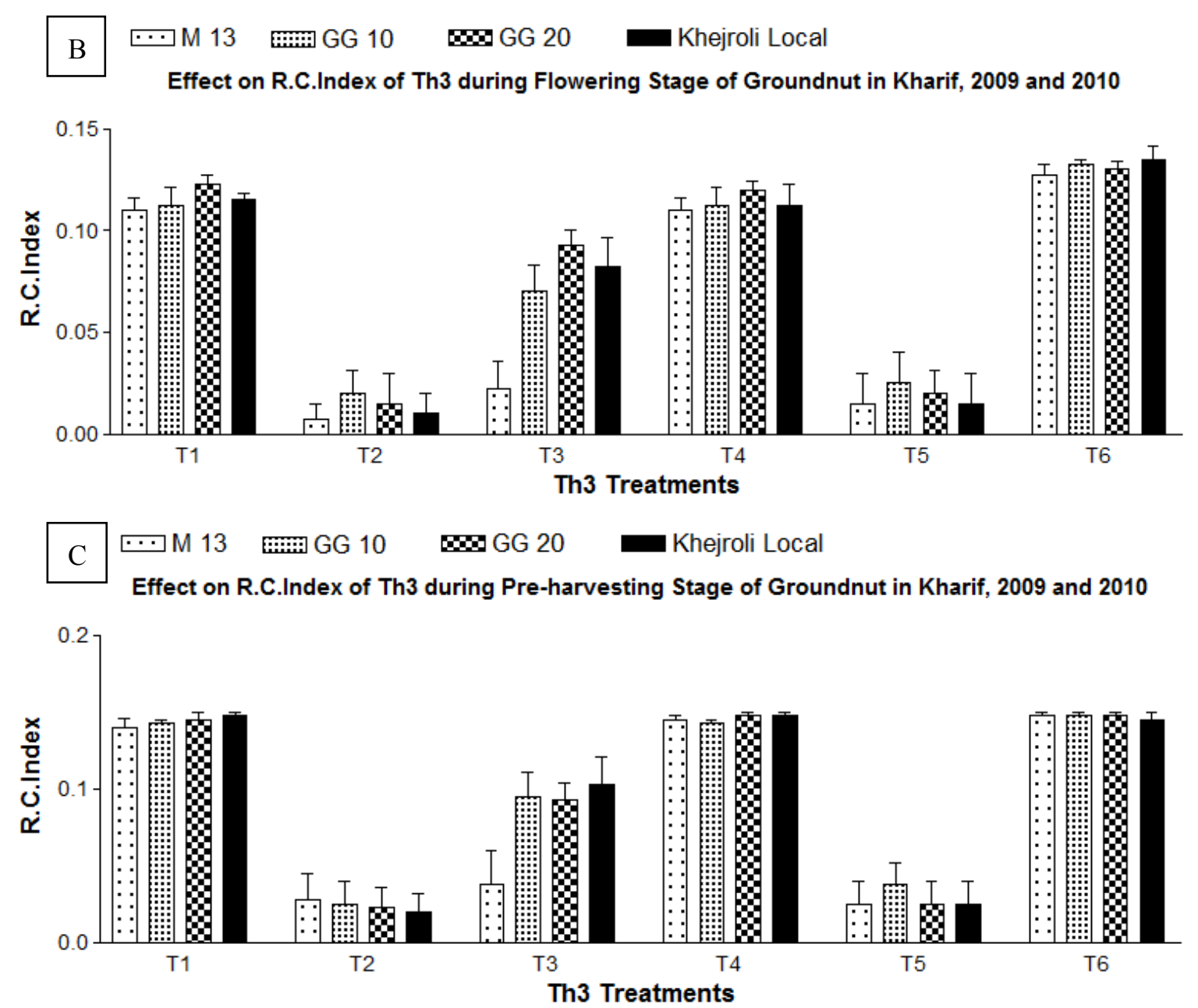

Figure 3. Effect of Trichoderma harzianum (Th3) treatment on Rhizospheric Competence (R.C.) Index of Th3 during A. Seedling, B. Flowering and C. Pre-harvesting Stages of Groundnut at in summer (Kharif), 2009 and 2010. Error bar indicates $C D$ value at $p<0.0001$. Where, T1 to T6: Scheduled Th3 treatments

Similarly Trichoderma harzianum has been reported effective against major soil borne fungi in different crops viz., root rot (Rhizoctonia solani) in tobacco (Gveroska \& Ziberoski, 2011). Trichoderma viride and T. harzianum in a pot culture study reduced the collar rot incidence in groundnut caused by A. niger (Gajera et al., 2011). Application of essential oils integration with the bio-agent T. harzianum was found to be suitable, safe and cost-effective for controlling soil borne diseases like Faba bean root rot (Abdel-Kader et al., 2011). Similar observations were recorded with other species of Trichoderma for controlling soil-borne diseases. In greenhouse experiments, the application of $T$. viride with pungam cake at $5 \mathrm{~g} / \mathrm{kg}$ of soil markedly reduced root rot incidence compared to the control where only pathogen (Macrophominha pahseolina) was inoculated without any biological control treatment (Karthikeyan et al., 2006). Trichoderma virens showed biocontrol activity against sugar beet seedling damping-off caused by Rhizoctonia solani (Hanson, 2003). T. viride along with Pseudomonas fluorescens increased the biocontrol activity against stem rot of groundnut caused by Sclerotium rolfsii (Manjula et al., 2004). R.C. Indices of Th3 (Figure 3) are found maximum at the pre-harvesting stage of the crop. All the four varieties (M13, GG10, GG20 and Khejroli local) showed similar trend of results for the Th3 treatment. The interaction between plant-pathogen and the biocontrol agent, Trichoderma harzianum was effective as it controlled the diseases and also helped in growth promotion (Kleifeld \& Chet, 1992; Inbar et al., 1994; Khan \& Saxena, 1997). This is in accordance with the Strain T22 of T. harzianum, which increased plant growth and development and controls diseases (Harman, 2000). Biologically-active isolates TH3, TH10, TV4 and TV12 compatible with recommended doses of different fungicides like thiram, captan, iprodione, and mancozeb showed overall increased growth in tomato and cauliflower, in terms of plant vigour, root colonization and disease control, and indicated better performance of Trichoderma under solarized soils than non-solarized soils (Arora et al., 2004). The rhizosphere competence and root colonization study showed that the pesticide 
tolerant isolate of Trichoderma performed better as compared to wild isolates in terms of disease control, root colonization and increased vigour of tomato and cauliflower plants under both solarized and non-solarized soils (Sharma, 2008). The active metabolites which reduce the pathogen activity were also tested in vitro and found that the partially purified active metabolites of Trichoderma isolates were very much effective even at very low concentrations. Use of Th3 bio-formulation along with the routine farmers' practice in field increased the yield and reduced root rot symptoms to a negligible rate. The community-based Trichoderma multiplication in different agri-wastes and its utilization brought the confidence among the farmers under conservation agriculture, reduced the input prices of crop protection and helped in quick adaption and dissemination of new technology for groundnut growers in Rajasthan state. The result in the present study summarized that Th treatment had ensured higher economic returns as well as higher yield with less groundnut root rot incidence. Similar observations were made by Ahuja et al. (2011) for IPM study including Trichoderma harzianum bio-formulation application on Cauliflower fields.

\section{Acknowledgments}

DG, ICAR, Director, IARI, Head, Plant Pathology and Financial support by DST-TIFAC, through project entitled "On farm Demonstration and Commercial production of Trichoderma as Biopesticide and Growth Promoter" is duly acknowledged.

\section{References}

Abdel-Kader, M. M., El-Mougy, N. S., \& Lashin, S. M. (2011). Essential oils and Trichoderma harzianum as an integrated control measure against Faba bean root rot pathogens. Journal of Plant protection Research, 51(3), 306-317.

Ahmad, J. S., \& Baker, R. (1987). Rhizosphere competence of Trichoderma harzianum. Phytopathology, 77, 182-189.

Ahuja, D. B., Ahuja, U. R., Srinivas, P., Singh, R. V., Malik, M., Sharma, P., \& Bamawale, O. M. (2012). Development of Farmer-led-Integrated management of major pests of Cauliflower cultivated in rainy season in India. Journal of Agricultural Sciences, 4(2), 79-90.

Arora, S., Sharma, P., \& Gopal, M. (2004). Compatibility of fungicide, iprodione with Trichoderma harzianum. Annals of Plant Protection and Science, 12, 222-223.

Basu, M. S., \& Ghosh, P. K. (1995). The status of technologies used to achieve high groundnut yields in India. In Achieving High Groundnut Yields. Patancheru, ICRISAT.

Chet, I. (1990). Biological control of soilborne pathogens with fungal antagonists in combination with soil treatments. In D. Hornby, R. J. Cook, Y. Henis, W. H. Ko, A. D. Rovira, B. Schippers, and P. R. Scott (Eds.). Biological Control of Soil-borne Pathogens (pp. 15-25). New York: CAB Publishing House.

Cortes, C., Gutierrez, A., Olmedo, V., Inbar, J., Chet, I., \& HerreraEstrella, A. (1998). The expression of genes involved in parasitism by Trichoderma harzianum is triggered by a diffusible factor. Molecular and General Genetics, 260, 218-225.

Devaki, N. S., Bhat, S. S., Bhat, S. G., \& Manjunatha, K. R. (1992). Antagonistic activities of Trichoderma harzianum against Pythium aphanidermatum and Pythium myriotylum on Tobacco. Journal of Phytopathology, 136(1), 82-87. http://dx.doi.org/10.1111/j.1439-0434.1992.tb01284.x

Gajera, H., Rakholiya, K., \& Vakharia, D. (2011). Bioefficacy of Trichoderma isolates against Aspergillus niger Van Tieghem inciting Collar Rot in Groundnut (Arachis Hypogaea L.). Journal of plant protection research, 51(3), 240-247. http://dx.doi.org/10.2478/v10045-011-0040-x.

Guanlin, X., Pamplona, R., Cottyn, B., \& Mew, T. W. (1997). Rice seed- Source of naturally occurring biological control agents. In A. Ogoshi, K. Kobayashi, Y. Homma, F. Kodama, N. Kondo, and S. Akino. Proceedings of the Fourth International Workshop on Plant Growth Promoting Rhizobacteria: Present Status and Future Prospects. October 5-10, (pp. 445). Sapporo, Japan.

Gveroska, B., \& Ziberoski, J. (2011). The influence of Trichoderma harzianum on reducing root rot disease in tobacco seedlings caused by Rhizoctonia solani. International Journal of Pure and Applied Sciences and Technology, 2(2), 1-11.

Hanson, L. E. (2003). Biological control of damping-off in sugarbeet seedlings with Trichoderma species. 1st Joint IIRB-ASSBT Congress. 27 Feb. - 1 Mar., San Antonio, Texas, USA.

Harman, G. E. (2006). Overview of mechanisms and uses of Trichoderma spp. Phytopathology, 96, 190-194. 
http://dx.doi.org/10.1094/PHYTO-96-0190.

Harman, G. E., \& Kubicek, C. P. (1998). Trichoderma and Gliocladium. (Vol. 2). Enzymes, Biological Control and Commercial Applications. London: Taylor \& Francis, London.

Harman, G. E. (2000). Myths and dogmas of biocontrol. Changes in perceptions derived from research on Trichoderma harzianum T-22. Plant Disease, 84, 377-393.

Inbar, J., Abramsky, M., Cohen, D., \& Chet, I. (1994). Plant growth enhancement and disease control by Trichoderma harzianum in vegetable seedlings grown under commercial conditions. European Journal of Plant Pathology, 100, 337-346. http://dx.doi.org/10.1007/BF01876444.

Jain, P. K., Singh, I. P., \& Kumar, A. (2005). Risk in Output Growth of Oilseeds in the Rajasthan State: A Policy Perspective. Agricultural Economics Research Review, 18, 115-133.

Karthikeyan, V., Sankaralingam, A., \& Nakkeeran, S. (2006). Management of groundnut root rot with biocontrol agents and organic amendments. Archives of Phytopathology and Plant Protection, 39(3), 215-223. http://dx.doi.org/10.1080/03235400500094225.

Khan, T. A., \& Saxena, S. K. (1997). Effect of root-dip treatment with fungal filtrates on root penetration, development and reproduction of Meloidogyne javanica on tomato. International Journal of Nematology, 7, 85-88.

Kleifeld, O., \& Chet, I. (1992). Trichoderma harzianum - interaction with plants and effect on growth response. Plant Soil, 144, 267-272. http://dx.doi.org/10.1007/BF00012884.

Kubicek, C. P., Mach, R. L., Peterbauer, C. K., \& Lorito, M. (2001). Trichoderma: From genes to biocontrol. Journal of Plant Pathology, 83, 11-23.

Lavelle, P., \& Spain, A. V. (2001). Soil Ecology: Kluwer Academic Publishers, Dordrecht; Boston

Manjula, K., Kishore, G. K., Girish, A. G., \& Singh, S. D. (2004). Combined Application of Pseudomonas fluorescens and Trichoderma viride has an improved biocontrol activity against stem rot in Groundnut. Plant Pathology Journal, 20(1), 75-80.

Manjula, K., Singh, S. D., \& Kishore, G. K. (2002). Role of endophytic bacteria in biological control of plant diseases. Annual Review of Plant Pathology, 1, 231-252.

Mishra, V. K. (2010). In Vitro Antagonism of Trichoderma species against Pythium aphanidermatum. Journal of Phytology, 2(9). 28-35.

Pattee, H. E., \& Young, C. Y. (1982). Peanut Science and Technology, American Peanut Research and Education Society, Taxas, USA: Inc. Yoakum.

Podile, A. R., \& Kishore, G. K. (2002). Biological control of peanut diseases. (pp. 131-160) In S.S. Gnanamanickam (Eds.). Biological control of crop diseases. New York, Marcel Dekker Inc.

Rajkonda, J. N., Sawant, V. S., Ambuse, M. G., \& Bhale, U. N. (2011). Inimical potential of Trichoderma species against pathogenic fungi. Plant Sciences Feed, 1(1), 10-13.

RamaRao, D., Kiresur, V. R., \& KalpanaSastry, R. (2000). Technological Forecasting of Future Oilseeds Scenario in India (ICAR-AP CESS Project). National Academy of Agricultural Research Management, Rajendranagar, Hyderabad.

Reddy, K. R. N., Reddy, C. S., \& Muralidharan, K. (2009). Potential of botanicals and biocontrol agents on growth and aflatoxin production by Aspergillus flavus infecting rice grains. Food Control, 20, 173-178. http://dx.doi.org/10.1016/j.foodcont.2008.03.009.

Sharma, P., Kulshrestha, G., Gopal, M., \& Kadu, L. N. (2004). Integrated Management of Chilli Die Back and Anthracnose in Delhi Region. Indian Phytopathology, 57(4), 427-434.

Sharma, P. (2008). Effect of cropping system on rhizospheric competence of T. harzianum and growth performance of important vegetable crops. Journal of Ecofriendly Agriculture, 3(2), 185-189.

Sharma, P., \& Dureja, P. (2004). Evaluation of T.harzianum and T.viride isolates at BCA Pathogen Crop Interface. Journal of Mycology and Plant Pathology, 34(1), 47-55.

Sharma, P., Kadu, L. N., \& Sain, S. K. (2005). Biological management of dieback and fruit rot of chilli caused by Colletotrichum capsici (Syd.) Butler and Bisby. Indian journal of plant protection, 33(2), 226-230.

Sharma, P., \& Sain, S. K. (2003a). Evaluation of commercial and laboratory formulations of bioagents and plant 
nutrients against wilt of tomato and damping off of cauliflower. Indian Journal of Plant Pathology, 21, 105-109.

Sharma, P., \& Sain, S. K. (2003b). Development of suitable techniques for evaluating virulence and biocontrol activity of Trichoderma isolates. Indian Journal of Plant Pathology, 21, 16-21.

Sharma, P., \& Sain, S. K. (2004). Induction of systemic resistance in tomato and cauliflower by Trichoderma species against stalk rot pathogen. (Sclerotinia sclerotiorum). Journal of Biocontrol, 18(1), 21-28.

Sharma, P., \& Sain, S. K. (2005). Use of biotic agents and abiotic compound against damping of cauliflower caused by Pythium aphanidermatum. Indian Phytopahology, 58(4), 395-401.

Sharma, P., Sain, S. K., \& James S. (2003). Compatibility Study of Trichoderma isolates With Fungicides against Damping-off of Cauliflower and Tomato caused by Pythium aphanidermatum. Pesticide Research Journal, 15(2), 133-138.

Sharma, P., Sharma, S. R., Sain, S. K., \& Dhandpani, A. (2006). Integrated management of major diseases of cauliflower (Brassica oleracea var.botrytis subvar cauliflora). Indian Journal of Agricultural Sciences, 76(12), 726-731.

Sharma, P., Singh, L., \& Adlakha, D. (2001). Antagonistic potential of Trichoderma and Aspergillus species on Sclerotinia sclerotiorum (Lib.) de Bary causing rots in cabbage and cauliflower. Pesticides Information, 2, 41-44.

Sharma, P., Vignesh Kumar, P., Ramesh, R., Saravanan, K., Deep, S., Sharma, M., Saini, M., \& Singh, D. (2011). Biocontrol genes from Trichoderma species- A Review. African Journal of Biotechnology, 10(86), 19898-19907. http://dx.doi.org/10.5897/AJBX11.041.

Sharma, R. C. (1982). Studies on groundnut root-rot caused by Macrophomina phaseolina (Tassi) Goid (Rhizoctonia bataticola) (Taub.) Butler, Ph.D. Thesis. Indian Agricultural Research Institute, New Delhi, India.

Weiss, E. A. (2000). Oilseed Crops: Blackwell Science. London.

Yedidia, I., Benhamou, N., \& Chet, I. (1999). Induction of defense response in cucumber plants (Cucumis sativus L.) by the biocontrol agent Trichoderma harzianum. Applied and Environmental Microbiology, 65, 1061-1070.

Zewain, Q. K., Bahadur, P., \& Sharma, P. (2005). Integrated disease management of stalk rot of cauliflower. Indian Phytopathology, 58(2), 167-173.

Zhang, C. 1., Druzhinina, I. S., Kubicek, C. P., \& Xu, T. (2005). Trichoderma biodiversity in China: Evidence for a North to South distribution of species in East Asia. FEMS Microbiology Letters, 251, 251-257. 